\title{
NASCEU UMA CRIANÇA NA “SARJETA”: E AGORA?*
}

A CHILD WAS BORN IN THE GUTTER: NOW WHAT?

Aparecida Magali de Souza Alvarez ${ }^{1}$

ALVAREZ, A. M. S. Nasceu uma Criança na "Sarjeta”: E Agora? Rev. Bras. Cresc. Des. Hum., São Paulo, n(2), 1994.

Resumo: Este texto focaliza o caso de uma jovem mulher que, contrariando as expectativas comuns para o tipo de populac,ão da qual fez parte, ou seja, "moradores de rua/selvagens” (Rabinovich, 1992), fez uma transição gradativa para outro tipo de vida com o nascimento de seu filho.

Com este estudo de caso, a autora procura trazer à luz a riqueza do perfil e expectativas de alguns participantes desse grupo de seres humanos, moradores das sarjetas da cidade de São Paulo, resgatando-os do anonimato de simples componentes de dados estatísticas.

Palavras-chave: moradores de rua, criança, família, base segura, expectativas sociais.

Summary: This text focuses on a case of a young woman who, contradicting what is commonly expected from the population she was part of, that is, the homeless "savages" (Rabinovich, 1992), gradually changes her Iifestyle with the birth of her son. With this case study, lhe author attempts lo bring to light lhe richness of lhe profile and expectations of some members of this immense group of human beings gutter dwellers of the city of São Paulo - rescuing them from the anonymity of simple statistics.

Key-words: homeless, child, family, secure basis, social expectancy.

* A palavra “sarjeta”, no título, está sendo usada no sentido metafórico, referindo-se às condicões hostis da vida de uma populacão de rua.

1 Psicóloga Clínica. Pesquisadora do Centro de Estudos do Crescimento e do Desenvolvimento do Ser Humano, Faculdade de Saude Pública/USP.

End.: Av. Dr. Arnaldo 715, sala 21, São Paulo - SP, CEP 01246 904 Fone/Fax: (011) 851.3572 


\section{INTRODUÇÃO}

RABINOVICH (1992) em sua pesquisa “A casa dos sem-casa” explicita uma categoria de moradores de rua como sendo "selvagens"2. Segundo este autor, "os selvagens são os moradores das sarjetas; não demarcam seu território, só possuem o que podem carregar consigo. E a radicalização do grupo nómade: a ausência de casa parece estar relacionada à total ausência de perspectivas. Segundo um deles: 'Daqui, só para a morte’. Os selvagens trabalham como guardadores de carro, carregadores de caminhão e trabalhos eventuais. Alimentam-se e dormem erradicamente, não estruturam famílias, mas podem formar 'gangs"' (pág. 20).

O interesse em conhecer tal categoria motivou o presente estudo, levando a autora a integrar-se a um grupo de pessoas que, toda quartafeira, à noite, levava sopa quente a alguns moradores de rua da cidade de São Paulo.

A cada noite eram visitados alguns "postos” (como eram chamados, pelo grupo, os locais onde usualmente os moradores de rua reuniam-se para morar).

Em alguns destes postos, havia um grupo de pessoas, sem laços de parentesco, que moravam na calçada de uma esquma próxima ao Viaduto Pedroso, na cidade de São Paulo.

Não construíram ali qualquer tipo de casa ou proteção: dormiam ao relento, sobre panos ou eventuais colchões que recolhiam a esmo. "Só possuem o que podem carregar” (RABINOVICH, 1992); porém, numa pequena variação da categoria dos "selvagens”, demarcaram um território: a calçada daquela esquina ou, eventualmente, uma pequena praça à frente da mesma esquina.

Já no primeiro contato com esse grupo a autora encontrou Célia ${ }^{3}$, 21 anos, grávida de 8 meses, que se aconchegava ao companheiro, também morador de rua, procurando aquecer-se junto a uma fogueira acesa na praça.

Este artigo focaliza essa mulher que, contrariando as expectativas comuns para o tipo de população da qual fez parte (moradores de rua/“selvagens”), fez uma transição gradativa para outro tipo de vida com a chegada de seu filho.

Este estudo situa-se dentro de uma visão fenomenológica explicitada por FIGUEIREDO (1992): “é uma obra aberta, ou seja: ...intrinseca- mente incompleta e lacunar. No entanto é preciso cuidado para que estes qualificativos não sejam compreendidos a partir de uma nostálgica aspiração à totalidade. Não, na obra aberta, as lacunas que se abrem entre um conjunto mais ou menos heterogéneo de notas e fragmentos, funcionam como convites para que o leitor se introduza ele mesmo neste tecido esgarçado. As lacunas instauram campos abertos à diversidade interpretativa e às variadas fruições e intervenções. Para que as brechas, contudo, sejam efetivamente convites é preciso que o texto, de alguma forma implique os leitores nas suas questões, ou seja, neste processo propiciador de novas descobertas e fenomenalizações”.

Através de observações e, também, em entrevistas abertas feitas com Célia e seu companheiro, foram resgatadas algumas experiências dessa jovem mãe, de sua “jovem família” e do "grupo da esquina”.

\section{DESCRIÇÃO DO CASO: ALGUNS FRAGMENTOS DE VIDA E DE CONVERSAS}

Célia ficou sem a proteção da mãe desde pequena (não precisou a idade) quando foi morar com uma mulher que a espancava muito.

Fugiu da companhia dessa mulher e voltou até sua mãe que lhe negou amparo. Ficou revoltada:

- Na hora que eu mais precisei dela, ela não me acolheu... então, sei lá, eu tenho uma revolta...

Foi para a rua. Morou doze anos na Praça da Sé, na Praça da República, até que, finalmente, instalou-se na região do Viaduto Pedroso e imediações, onde a autora a conheceu grávida de oito meses.

Já quase no momento de ter o bebé, ela e seu companheiro começaram a preocupar-se com um lugar melhor para ficar. Encontraram um quarto, num casarão invadido por várias pessoas (dezasseis adultos e dez crianças). Instalou-se com o companheiro, continuando, no entanto, a frequentar a esquina e a pracinha onde estavam seus antigos amigos, como ela os chamava.

Algumas vezes a Prefeitura (referência utilizada pelos moradores) passava nessa esquina e retirava os colchões e demais pertences de seus amigos. Ficavarn sem ter com que dormir mas, não se retiravam do local. Viviam bêbados e pedindo esmolas. Às vezes, brigavam entre si e um deles, mais exaltado, furava alguém com faca.

2 Segundo esta autora, em comunicado pessoal de 1995, os sem-casa "selvagens” de São Paulo têm aumentado em número expressivo nos últimos anos. Redes de apoio mútuo e social têm crescido concomitantemente, assim como o convívio da população com uma situação “de fato". Isto estaria possibilitando este modo de morar como uma opção "alternativa” de vida. Neste sentido, estaria sendo construída uma identidade "selvagem” que consegue articular passado e futuro, através do presente, de modo a possibilitar a vida e não apenas a "sobrevida” ou a morte.

3 Os nomes reais dos personagens foram trocados. 
Uma componente do grupo, assim justificava a bebida alcoólica que ingeriam:

- Um dia, tapa todo mundo triste aqui. Aí, eu ganhei "cinco pau” comprei pinga pra todo mundo e $f$ ice todo mundo alegre! Falava e ria embebedada...

Célia teve seu filho e continuou morando no quarto do casarão.

Quando a autora manifestou o desejo de visitar o bebe, um dos moradores da esquina, o “Cara Queimada” (apelidado assim porque alguém ateou-lhe fogo ao rosto, na rua, ficando deformado), prontificou-se a levá-la. Bastante impregnado pela bebida mas, consciente do caminho, levou-a até ao local. Em alguns cómodos estavam instaladas pessoas, algumas com evidentes sinais de alterações mentais (pelo efeito de drogas?).

Célia recebeu a autora enrolada em um cobertor e levou-a, através de uma escadaria, até ao alto do casarão, para o seu quarto.

Este estava mobiliado com dois armários, fogão, geladeira velha, colchão de casal no chão (sobre o qual estava o bebe), um banquinho de madeira. Vários quadros de santos e pôsteres enfeitavam as paredes. Várias roupas secavam nos varais estendidos pelo cómodo.

“Cara Queimada” dirigiu-se até ao beba, deitou-se a seu lado e começou a brincar com ele, fazendo-lhe gracinhas.

Começou a conversa com Célia. A autora perguntou-lhe se poderia gravá-la e ela aceitou.

\section{Célia e seu bebé: expectativas}

Contou ser esse o seu primeiro filho. Há tempo tinha vontade de ter um filho mas, não conseguia engravidar (já o tentara com um companheiro anterior).

Chegou a consultar um médico que lhe dissera ser estéril.

Quando conheceu e apaixonou-se por Hélio, morador de rua como ela, resolveram ficar juntos; após dois anos, pediu para ele:

- Mô (é assim que o chama na intimidade), ramo te um neném?

Ele achou muito cedo para isso. No entanto, ela engravidou e, quando percebeu, já está com cinco meses de gravidez.

Ela e o companheiro ficaram felizes e ele ficou, também, preocupado:

- Será que vamos ter condições?

Ela relatou:

- De noite, quando eu lava dormindo, ele tinha o maior cuidado pra não bater na minha barriga, sempre passava a mão na minha barri- ga pró vê como é que o neném se mexia. Ele ficava todo bobo. Nós ficamo dois crianção!

Quando começou a sentir as primeiras contrações, buscou auxílio no Hospital Municipal. A médica examinou-a, constatou que já estava com quatro dedos de dilatação mas disse que não havia vaga para interná-la. Mandou-a para o Amparo Maternal.

Célia perguntou:

- Como é que eu faço?

A médica respondeu:

- Você pega o Metrô, desce do Metrô, e pá, pá, pá... Assim Célia descreveu a fala da doutora. E continuou:

- Ficamo ali na porta do Metrô esperando abri. Deu cinco hora da manhã (ela e o marido esperaram por uma hora), peguei o Metrô.

Desceram na estação indicada e foram à pé até ao Amparo Maternal. Sofreu muito no caminho com as contrações. Por vezes, Hélio a carregou no colo. mal.

No hospital, o beba nasceu de parto nor-

Célia continuou:

- O médico falo: "É um menininho, forte, nasceu com três quilos e sessenta, não tem nada, é saudável. Na hora eu chorei de emoção, de vê 0 neném assim, porque o médico falô que eu nunca ia pode te neném. E o mais importante foi dizê que era um menininho...

Eu queria um menino, porque menino, sei lá... eu já sofri bastante, é duro sê mulhé. Porque você sê mulhé e tando na rua os home gosta muito de quere aproveita, de quere abusá de você. E o hoine não, o home já tem uma cabeça mais diferente... de repente, nunca sei o dia de amanhã, né? E o home não vai sofre tanto...

Ante a indagação sobre o que ela havia "sonhado” ou “desejado” para esse filho, ela respondeu:

- Principalmente dá muito amo e carinho, uma coisa que nunca tive de mãe.

Dá bastante atenção pra ele, que ele cresça, estude, seja alguém na vida. Eu não tive estudo, estudei só até a primeira série, sei escreve e lê mas por esforço meu. Agora, eu quero bastante coisa pró ele. Que ele não ande na rua, que não saiba o que é droga, o que éficá na rua e dormi na rua. Essas coisa eu não quero que aconteça com ele, que eu sei o que é...

Disseram pro Hélio que o menino num era filho dele. Foi uns amigo de araque. 
Quando o menino nasceu, ele foi seco no menino... porque o interesse dele era vê o menino pró ve se era verdade que não era dele. Quando bateu o olho, ele ficou parado... Eu falei: É, tomou um choque agora, nó? Aí, ele olhou pró mim, assim, e chora... Catô o menino no colo e chora. Ele tem um chamego danado com esse menino.

Quando a gente começa a viva junto ele comece a pará de bebê.

Célia era cuidadosa com seu bebê. Levava-o ao médico, procurou mantê-lo limpo (dois banhos por dia), dava vitaminas apropriadas à idade (que conseguia com o médico que é o responsável pelo grupo "da sopa”), oferecia mamadeiras adequadas. Mostrou, orgulhosa, a caderneta de vacinas do bebê. disse:

Ao descrever esses cuidados com o bebê,

- Eu quefico o dia intero com ele, fico aqui lavando sopa, cuidando da casa, dó banho nele cedo, quando lá quase escurecendo dó outro banho nele pró ele dormi mais fresquinho, porque quando o calor tá forte ele fica enjoado. Aí troco ele, deixo ele bem arrumadinho, cheirosinho, limpinho. Quando o pai dele chega a primeira coisa que faz é olhar pão menino e dizê:

- Ah, nego, ó o pai, cade o pai?

Não conseguiu ainda registrar o bebê porque estava esperando o companheiro tirar a carteira de identidade. Segundo ela, sem a identidade do pai o cartório não registrava o bebê.

A saida do casarão, a autora voltou à "esquina” e lá encontrou Hélio. Ele diz:

- Já morei na rua; agora não, graças a Deus, eu tenho ali (referiu-se ao quarto no casarão). Tenho o lugar onde guardo minha carroça de catar papel...Por aí vou tocando a vida... Não é por mim, mais; agora é por ele, meu filho... Não tenho o que fazer por mim mais, agora é por ele...

\section{REFLEXÕES}

Discorrendo sobre a Família, Relativismo Cultural e Injustiça Social no Campo do Desenvolvimento Humano, LEFÈVRE (1994) conclui que, em países como o nosso uma luta se desenha no horizonte do campo do desenvolvimento humano, "para que todas as crianças possam ter a possibilidade de se desenvolver num contexto familiar de uma formação sócio-cultural que ofereça um amplo leque de opções culturais".
E diz mais: "É preciso constatar, por outro lado, que, em nosso país, estamos ainda longe desta possibilidade, para a grande parte de nossas fam^l1ias, para as quais ainda é necessário que se façam cumprir os preceitos de documentos legais como o Estatuto da Criança e do Adolescente, que postula, para as famílias e para as suas crianças e adolescentes, direitos elementares de cidadania que Ihes assegurem um mínimo de condição humana” (pág. 44).

Essa condição humana que faltou à Célia não foi suficiente para desumanizá-la.

Conservou seu sonho de maternidade, acalentou-o persistentemente, mesmo morando na cidade de São Paulo na condição de selvagem.

Fez a sua parte: manteve-se viva nesse ambiente inóspito, preservou-se e, agora, quer inserir-se e inserir o filho em um contexto social melhor, fazê-lo cidadão.

Relata WINNICOTT(1988) que, "no caso da maior parte dos bebes, o falo de serem desejados e amados pelas mães, pais e demais membros da família fornece-lhes o contexto no qual cada criança tem a oportunidade de se tornar um indivíduo, não apenas realizando seu destino seguindo a trajetória do legado hereditário (na medida em que a realidade exterior o permita) mas, também, feliz por ser capaz de identificar-se com as outras pessoas, animais e coisas do meio ambiente, bem como com a sociedade e sua perpétua autoorganização".

Célia pareceu não ter desejado vivenciar somente a experiência biológica da procriação, ou seja, da gravidez e parto. Ela quis mais: renascer nesse filho, reservar-lhe seus mais escondidos e acalentados sonhos de uma vida melhor, de um futuro promissor, mais promissor que 0 seu.

Vivenciou a díade formada por mãe e bebê.

Pela sua dedicação ao filho, pela "maternagem suficientemente boa” (WINICOTI, 1988), pela "base seguram (BOWLBY, 1989) que lhe ofereceu e tem oferecido, à despeito de todas as privações que passou e passa, as palavras de innicott poderiam ser-lhe atribuídas: "Sou confiável - não por ser uma máquina, mas porque sei do que você está precisando; além disso, me preocupo, e quero providenciar as coisas que você deseja. Isto é o que chamo de amor neste estágio do seu desenvolvimento".

O bebê, com o que ainda WINNICOTI (1988) chama de "segurar e manipular suficientemente bons" de sua mãe (e pai), responde com

4 Base segura "ponto central de um comportamento de cuidados. É a partir de sua provisão, pelos pais, que uma criança ou um adolescente podem explorar o mundo exterior e a ele retornar certos de que serão bem vindos, nutridos física e emocionalmente, confortados se houver um sofrimento e encorajados se estiverem amedrontados. Essencialmente, é estar disponível, pronto para responder quando solicitado, para encorajar...” 
o seu desenvolvimento, com a realização de seu potencial hereditário.

Mas, por agora, isso é tudo 0 que Nédia e seu companheiro têm conseguido prover e providenciar, no minúsculo quarto à guisa de casa no imenso casarão invadido.

Resta a pergunta: Conseguirá fazer do filho um alguém, como deseja?

Curtida no sofrimento da vida nas ruas, acostumada a contar só consigo mesma na sobrevivência na serva humana, a própria Cedia respondeu a essa questão quando colocou sua dúvida na possibilidade do sucesso:

- Eu queria um menino, porque menino, sei lá... eu já sofri bastante, é duro sê monhé. Porque você sê monhé e tando na rua os home gosta muito de quere aproveita, de quere abusa de você. E o homem não, o home já tem uma cabeça mais diferente... de repente, nunca sei o dia de amanhã, né?

E, numa fantasia ingénua, acrescentou: - ...e o home nao vai sofre tanto...

\section{BIBLIOGRAFIA}

BOWLBY, J. Uma base segura: aplicações clínicas da teoria do apego. Porto Alegre, Ed. Artes Médicas, 1989.

FIGUEIREDO, L. C. M. Um método para o pensamento débil: há seriedade nisso? Comunicação apresentada no $4^{\circ}$ Encontro Regional de Psicologia da ABRAPSO, São Paulo, maio, 1992.

LEFÈVRE, F. Família, relativismo cultural e injustiça social no campo do desenvolvimento humano. Rev. Bras. Cresc. Des. Hum., IV( 1 ): 40-44, 1994.

RABINOVICH, E. P. A casa dos sem-casa Psic. Cienc. e Prof., 12(3/4): 1 6-23, 1992.

WINNICOTI, D. W. Os bebês e suas mães. São PauIo, Ed. Martins Fontes, 1988.

recebido em: 05/03/95 aprovado em 03/04/95 